\title{
The Positive Effect of Evaluation on Improving E-learning Courses Addressed to Adults: A Case Study on the Evolution of the GSLLLY Courses in Greece over a Decade
}

\author{
Maria Pavlis Korres ${ }^{1}$ \\ ${ }^{1}$ General Secretariat for Lifelong Learning and Youth, Greece \& Hellenic Open University, Greece \\ Correspondence: Maria Pavlis Korres, General Secretariat for Lifelong Learning and Youth, Greece \& Hellenic Open \\ University, Greece.
}

Received: October 24, 2016

Accepted: November 20, 2016

Online Published: November 23, 2016

doi:10.11114/jets.v5i1.1940

URL: http://dx.doi.org/10.11114/jets.v5i1.1940

\begin{abstract}
The General Secretariat for Lifelong Learning and Youth (GSLLLY), the strategic national entity for Adult Education in Greece, has designed and implemented various e-learning courses offering flexibility beyond time and space restrictions. The courses run in two consecutive periods, the first one from 2008 to 2011 and the second one from 2014 to 2016. This paper is focusing on key design and implementation features of the courses in both periods and is analyzing the ways and the level by which the evaluation of the courses of the first period affected positively the design of the courses in the second period by enhancing the strengths and rectifying the weaknesses. Further on the evaluation results of the second period courses clearly showed that the majority of the first period problems have been solved and provided useful material for further improvement.
\end{abstract}

Keywords: e-Lifelong Learning Centers (e-LLLC), e-learning, online teaching, adult education, evaluation

\section{Introduction}

The General Secretariat for Lifelong Learning and Youth (GSLLLY) is the strategic national entity for Adult Education in Greece. The GSLLLY has been a pioneer in adult education for more than 30 years, through the design and implementation of courses addressed to the general population as well as to vulnerable social groups. The majority of these courses have been implemented face to face while in the last decade the exploitation of Information and Communication Technologies has allowed the design and implementation of e-learning courses, making knowledge accessible to larger groups, without the limitations of time and space (Bonk, 2009; Paneer Selvam, 2009 ).

In the present paper, the key features on design and implementation of the courses run over two periods - 2008 to 2011 and 2014 to 2016 - are examined while focusing on how and to what extent the evaluation of the first period courses have been used to improve design and implementation of the second period courses. Furthermore, the main results of the second period courses evaluation are presented, with suggestions for improvement of similar courses in the future.

\section{The First Period Courses: 2008-2011}

These courses have been the first attempt to materialize e-learning programs and took place from 2008 through 2011 at national scale. The courses were co-financed by the European Social Fund and national resources; they were designed by the GSLLLY and implemented by the Institute for Continuing Adult Education (IDEKE in Greek) under the supervision of GSLLLY.

The courses provided free e-learning to any interested citizen, over 18 years old with the sole prerequisite of certification on basic computer skills. Learners were selected by draw as the number of applications exceeded the number of positions available.

The courses were addressed mainly at learners who had completed secondary education and wanted to upgrade their knowledge and skills or acquire new ones in the following thematic areas:

- Information and Communication Technologies-250 hours

- Economy-Management-Enterprise-250 hours 
- Environment and Sustainable Development-250 hours

- Culture-Tourism-Regional Development-250 hours

- Social Economy \& Entrepreneurship-125 hours

Each thematic area was divided into 5 modules, 50 hours each, except the last one, which was divided into only 3 modules. Each module lasted 8 weeks and demanded approximately 6 hours of study per week.

The courses were very popular in Greece as the learners were able to participate at flexible time and place and integrate learning in their daily professional, personal and social program. The courses were attended by 5.886 adults in total (IDEKE, 2011a).

The courses were organized and run by the Distance Learning Center (DLC), through a central unit in Athens and the 27 regional educational units, situated in the 13 prefectures of Greece. The Learning Management System (LMS) which was a customized version of the Moodle platform (version 1.6).

A blended learning model was adopted, combining traditional adult learning methods with distance learning methods. For each module, the learners had three face-to-face meetings which lasted four hours, and took place in the beginning, the middle and the end of the module. The face-to-face classes were held at the regional educational unit of each prefecture, and were mandatory. During the asynchronous learning sessions the learners' obligations were to study the educational material (mainly narrated power point slides and complementary material in the form of word and/or pdf documents), to complete self-assessment and a graded test in each module. The communication tools available were the e-mail and the forum, but their use by the learners was limited. Learners were assessed on their active participation in live meetings, the completion of assignments, as well as on their performance in a final test. At the end of the course, a certification of attendance was provided to all learners who successfully completed the course.

During the same period, the GSLLLY run specialized blended e-learning courses for the training of educators and staff members occupied in all GSLLLY courses. These courses have been attended by 9.243 attendees (IDEKE, 2011b).

\subsection{Evaluation of the First Period Courses}

The courses have been evaluated through internal and external evaluation.

The internal evaluation was carried out through questionnaires addressed to learners, interviews with the Program Administrator and the IT Administrator, as well as the content analysis of the scientific reports for each thematic area and its modules. The evaluation focused on the quality and specifications of the courses throughout the educational procedure. Fields of evaluation were: the infrastructure, the educational materials, the curriculum, the educators, the instructional methods and techniques, the quality of the outcome regarding the knowledge and the skills acquired by the learners, as well as the usefulness of this knowledge and skills to their personal, professional and social development.

The main conclusions coming out of the internal evaluation were (Pavlis-Korres, 2011; Pavlis-Korres, 2013):

a) The vast majority of the learners found the courses satisfactory and stated that they would like to attend e-learning courses again. Only $0.8 \%$ stated that they would not attend another e-learning course and a mere $1.4 \%$ stated they would prefer a face to face class.

b) Most learners capitalized the acquired knowledge and skills in their professional and personal life.

c) The educational material needed updating and enrichment, while the full exploitation of multimedia was suggested towards a more interactive environment.

d) The training of educators has been considered necessary on both teaching online and adult education.

e) The obtaining of knowledge and skills in computer use and the learning platform used by the learners was considered necessary before the beginning of the courses.

f) A substantial part of the learners (30.4\%) declared that they would prefer synchronous online meetings over face to face ones, but it should be noted that many learners, mainly from remote areas and islands, failed to attend the face to face meetings due to time and cost restrains, as well as difficulties in transportation caused by bad weather.

External evaluation materialized through questionnaires addressed to learners, educators and administrative staff, and interviews with the key persons in the program implementation. Apart from administration and budget issues the main problems spotted, which should be taken into consideration in future design, were (Neoanaylsis, 2011):

a) The educational platform did not fulfill the basic principles of the architectural structure of information and aesthetic in imagery which characterize the modern Learning Management Systems of this type. There was lack of usability, accessibility, and navigation, performance and design with negative results in the educational process, especially for beginners and low experience users. The need for an upgrade of the course software was also stressed. 
b) The updating of the educational material and its proper adaptation for the target groups was considered imperative.

c) A low percentage of participation of learners in the platform and the discussions in the forum was observed as the learners were familiarized with its use.

d) The need to employ educators more experienced in distance and online learning was obvious.

e) The creation of a teleconference hall to replace the face to face meetings.

Taking into consideration the conclusions of both internal and external evaluation the attendees had the opportunity to obtain, update or upgrade their knowledge, skills, and competencies, complementary to their formal education, their initial vocational training and their previous personal, social and professional experience (Leftheriotou \& Pavlis-Korres, 2014).

\section{The Second Period Courses: 2014-2016}

\subsection{Creation of the Municipal E-Lifelong Learning Centers (e-LLLC), also Known as e-Municipal Adult Education Centers}

In 2010 the Greek State established the creation of municipal Lifelong Learning Centers, offering educational programs of general adult education (Law 3879/2010).

The geographical particularity of Greece, with many remote mountainous areas and many islands, makes the implementation of conventional face to face educational courses very difficult and expensive. To confront this problem GSLLLY has designed e-learning courses, run through 14 e-LLLC in South Aegean islands with population under 1.500 (GSLLLY, 2012).

The e-LLLC courses offered general adult education aiming, through a multitude of thematic areas, to establish positive attitude towards learning, support equal opportunities to lifelong learning, strengthening of the ability to adapt to the continuously changing socio-economic conditions, participation in the "knowledge and information society", development of active citizenship, creative use of leisure time, improving access to the labor market, as well as the upgrading of the conditions of education, work and social situation of vulnerable group members (e-kdvm, 2015).

\subsection{The Design of the Second Period Courses Following the Experience and the Evaluation of the First Period Courses}

By reflecting on the basic elements of the evaluations of the first period courses and aiming to enhance the strong points and deal with the weaknesses the design team made a series of choices.

The first choice was the replacement of the face to face meetings by online meetings in synchronous mode, during which the educator and the learners are connected online to the educational platform in real time, enjoying two-way visual and audio communication (Bonk \& Cunnigham, 1998; Bonk, Wisher, \& Nigrelli, 2005; Melrose \& Bergeron, 2007). This way, not only the advantages of e-learning (reduction of transportation cost, lifting of space barriers) are exploited, but through the synchronous education mode the negative consequences of the learners' feeling of isolation, an issue of asynchronous e-learning, are reduced (Pallof \& Pratt, 2003; Lally \& Barret, 1999).

The educational model proposed by the scientific team was to begin two synchronous online meetings followed by an interchange of asynchronous and synchronous sessions closing with a last synchronous online meeting. Followed the adult education principles the educators were free to adapt the educational model according to the needs and the capabilities of the learners. However, it was suggested that the first and the last sessions should be synchronous as these sessions are most important for the development and the conclusion of the educational process (Pavlis Korres \& Nikolopoulou, 2015). The duration of synchronous educational online sessions was 2 to 3 hours.

The Learning Platforms used in e-LLLC were the Moodle for the asynchronous mode and the Big Blue Button (BBB) for the synchronous online sessions. The open source platforms were customized for the needs of the courses aiming to user-friendly and aesthetically attractive environment, as well as easiness of access and navigation. The online environment which resulted from the customization combined with the application of the basic adult education principles was appropriate for the promotion of interaction and communication through the use of various communication and collaborative tools (i.e. teleconference, e-mail, forum, chat, wiki).

The basic problems that had to be dealt with during the design and implementation of the courses, as well the ways to overcome them are presented in Table 1. 
Table 1. Problems and difficulties faced in e-LLLC and ways to overcome them

\begin{tabular}{|c|c|c|}
\hline Problem description & Who are facing the problem & Ways to overcome the problem \\
\hline $\begin{array}{l}\text { Limited learners' access in the } \\
\text { e-course due to lack of equipment } \\
\text { on the side of learners }\end{array}$ & Learners & $\begin{array}{l}\text { Municipal Lab with few computers in } \\
\text { common use }\end{array}$ \\
\hline Low Internet speed & Learners Educators & $\begin{array}{l}\text { Individual connections One connection for } \\
\text { all learners in the Municipal Lab }\end{array}$ \\
\hline \multirow[t]{4}{*}{$\begin{array}{l}\text { Insufficient } \\
\text { infrastructure }\end{array}$} & Municipality & $\begin{array}{l}\text { Provision of rooms equipped with } \\
\text { computers and internet connection as a } \\
\text { prerequisite for participation in the program }\end{array}$ \\
\hline & Learners & $\begin{array}{l}\text { Individual connection or use of the } \\
\text { municipality computer lab }\end{array}$ \\
\hline & Educators & $\begin{array}{l}\text { Individual connection and use of } \\
\text { microphones and cameras }\end{array}$ \\
\hline & INEDIVIM* & $\begin{array}{l}\text { Provision of Synchronous (Big Blue Button) } \\
\text { and asynchronous (Moodle) educational } \\
\text { platform }\end{array}$ \\
\hline $\begin{array}{l}\text { Technical difficulties before and } \\
\text { during the course }\end{array}$ & $\begin{array}{l}\text { The Responsible person from the } \\
\text { Municipality } \\
\text { Learners } \\
\text { Educators }\end{array}$ & $\begin{array}{l}\text { The existence of a Technical Support Team } \\
\text { in INEDIVIM* }\end{array}$ \\
\hline Preparation of the participants & Educators & $\begin{array}{l}\text { Training courses for the preparation of } \\
\text { educators }\end{array}$ \\
\hline & Learners & $\begin{array}{l}\text { Implementation of } 25 \text {-hour face to face } \\
\text { familiarization courses before the beginning } \\
\text { of the e-course }\end{array}$ \\
\hline $\begin{array}{l}\text { Lack of proper Educational } \\
\text { Material for online courses }\end{array}$ & $\begin{array}{l}\text { Educators } \\
\text { Learners }\end{array}$ & $\begin{array}{l}\text { Creation of new educational material } \\
\text { suitable for online courses } \\
\text { Training of the educators to create their own } \\
\text { educational material }\end{array}$ \\
\hline
\end{tabular}

* INEDIVIM is the evolution of IDEKE as the foundation responsible for the implementation of the courses.

A prerequisite for Municipalities wishing to participate in the project was the availability of either an IT lab, or a room with a number of computers so that citizens without a computer or internet connection at home could participate in e-courses. In fact, in most islands, during the initial online meetings, attendees preferred to gather in such places and participate as a group, with the help of the e-LLLC administrator, a fact that gave to these meetings a special character, different than the one originally designed. As the courses progressed, most courses developed in line with the initial model. There were even groups with attendees coming from different islands, a fact that promoted social networking between them.

Prospective attendees followed an introductory 25-hour face to face course (familiarization with e-learning), to get acquainted with the internet environment of their future e-education. Trainees' familiarization with the interface, according to Hillman, Willis and Gunawardena (1994), is an important factor for the development of the basic types of interaction in an online environment - interaction between educator and learner, interaction between learners and interaction between learner and content (Moore, 1989). By obtaining the skills that allow them to use fluently the e-education systems, learners can interact better with the content, their educator, and their co-learners, thus reducing the drop outs from the course, due to the increase of satisfaction coming from their participation (Rostaminezhad, Mozayani, Norozi, \& Iziy, 2013; Levy, 2007; Park \& Choi, 2009; Rovai, 2003).

Educators' training in the new e-learning environment is also important, in order for them to respond successfully to the difficult and demanding role of adults' e-educator (Moore \& Kearsley, 1996; Savenye, Olina, \& Niemczyk, 2001; Pavlis-Korres, 2010). By properly integrating the principles of adult education in an online environment, educators can contribute in confronting the sense of isolation that learners may experience, as well as the development of social interaction between learners and between learners and themselves, enhancing participants' satisfaction and the efficiency of the educational services offered (Gortan \& Jereb, 2007; Parker, 1999).

GSLLLY, faithful to its traditional recognition of the importance of the role and training of educators, carried out 3 seminars, in which 41 educators bound to run e-LLLC groups were trained. The seminars took place on-line, using the same synchronous and asynchronous platform, as the one they would use later for their own e-learning groups, while emphasis was given to the integration of adult education principles in an online environment.

As Pavlis Korres and Leftheriotou (2016) specifically stress, one of the main intentions in the development of e-LLLC's has been the integration of the principles and methods of adult education in educational courses using modern technology, the promotion of the digital environment in lifelong learning courses and the development of proper 
educational material, suitable for the e-learning of adults. Special attention was given to the educators' training in the development of educational material by using online tools, so that they would be capable of responding to the needs of their own learning group, by adapting or enriching the existing educational material. This was the case in several thematic areas, where the educators covered the shortage of educational material by creating their own.

Recognizing the importance of the educational material (Edelson, 2001; Henderson, Selwyn, \& Aston, 2015; Sawang, Newton, \& Kieren 2013), a group of specialists in digitizing adapted the educational material that had been developed by the Greek Open University for the existing live classes in LLC's, the result being a multimedia friendly material, promoting interactivity, the use of communication tools for the active participation of learners, the development of collaborative online learning forms, the promotion of the basic types of interaction, as well as critical thinking. Flipping books, animations, quizzes, online individual and group activities, wikis and other tools were created. In a period of two years, 18 thematic objects were digitized, following the demand.

\section{Main Findings during Implementation and Evaluation of the Second Period Courses and Discussion}

\subsection{Findings on the Implementation of the Courses}

The courses made available to several Greek islands appealed strongly to a large number of the inhabitants, while there was strong demand for their expansion in the rest of the country, a fact which already planned to materialize. 21 face to face courses on the familiarization with the platform took place and 69 e-learning courses were implemented in the period between October 2014 and June 2016 in which 1.235 learners participated. Table 2 shows the islands in which the 69 courses ran.

Table 2. Number of implemented courses in each island

\begin{tabular}{lcl}
\hline Island & $\begin{array}{l}\text { Number } \\
\text { of courses }\end{array}$ & $\begin{array}{l}\text { Number of citizens } \\
\text { (2011 population census) }\end{array}$ \\
\hline Kythnos & 1 & 1.436 \\
Serifos & 1 & 1.378 \\
Antiparos & 3 & 1.196 \\
Kasos & 4 & 1.070 \\
Chalki & 4 & 702 \\
Tilos & 5 & 829 \\
Leipsoi & 6 & 784 \\
Folegandros & 7 & 787 \\
Anafi & 9 & 273 \\
Nisiros & 9 & 982 \\
Kimolos & 10 & 899 \\
Astypalaia & 10 & 1.270 \\
Total & $\mathbf{6 9}$ & \\
\hline
\end{tabular}

Table 3. Courses implemented by thematic subject and island

\begin{tabular}{lcl}
\hline Theme of the course & $\begin{array}{c}\text { Number of } \\
\text { the courses }\end{array}$ & Island \\
\hline Alternative Tourism & 2 & Anafi (2) \\
$\begin{array}{l}\text { Alternative farming } \\
\text { Anxiety Management }\end{array}$ & 1 & Nisyros, \\
& 1 & Kimolos \\
Interpersonal & 1 & Kimolos \\
Relations Management & & \\
Theater workshop & 1 & Astypalaia \\
Art workshop & 2 & Leipsoi, Astypalaia \\
Russian Language & 2 & Nisyros, Tilos \\
Turkish Language & 2 & Chalki, Nisyros \\
Health Education/ & 2 & Chalki, Anafi, \\
$\begin{array}{l}\text { First Aid } \\
\text { Internal Decoration }\end{array}$ & 3 & \\
Spanish Language & 3 & Astypalaia, Nisyros, Kythnos \\
Photography & 6 & Kasos, Kimolos, Antiparos \\
Web design & 5 & Leipsoi, Astypalaia (2), Folegandros (2), Kimolos \\
Online tools and services & 1 & Leipsoi, Folegandros (2), Kasos, Anafi \\
in daily life & & Nisyros \\
Domestic beekeeping & 3 & \\
Biological Products & 5 & Anafi (2), Nisyros \\
English Language & 13 & Leipsoi, Folegandros, Chalki, Anafi, Nisyros \\
& & Astypalaia, Kasos, Kimolos (5), Anafi, Nisyros, \\
Italian Language & 16 & Tilos (3), Serifos \\
& & Leipsoi (2), Astypalaia (4), Folegandros (2), Kasos, \\
Total & $\mathbf{6 9}$ & Kimolos, Chalki, Antiparos (2), Anafi, Nisyros, \\
\hline
\end{tabular}


The thematic subjects of the courses which took place reflected the requests of the inhabitants of each island as presented in Table 3.

Naturally Table 3 shows, as expected, that most courses were on foreign languages (36 courses) due to the fact that islanders' main professional occupation is tourism. Next came creative use of free time (12), agricultural and domestic economy (11 courses), new technologies (6 courses), followed by psychology ( 2 courses) and health education (2 courses). Preference in Agricultural economy is understandable as is the next most important occupation in the islands. The choice of creative use of free time shows that people have developed interests in culture and art, maybe helping to pass the long winter months. New technologies seem important to those who would like to create their own websites for the promotion of their products or services.

\subsection{Findings from the Evaluation of the Second Period Courses and Discussion}

The evaluation of the second period courses was effected through online questionnaires completed by the learners in the end of the 2016 courses. The questionnaires contained closed and open questions and 122 learners from all the 14 e-LLLC's participated in the evaluation. Questionnaires were also completed by all the educators, while 4 hour online meetings took place between the educators and the GSLLLY design team on the evaluation of the courses.

From the multitude of findings, we are focusing on those related to the successful improvement of the courses design following the results of the evaluation of the first period courses. Our guidelines in this evaluation were the learners' overall satisfaction and their specific views on their educators, the educational material, as well as the successful design of the online environment and the communication tools. The views of the educators on the strengths and weaknesses of the courses, both in technical and pedagogical design, were also seriously considered.

Learners' satisfaction is considered a key issue when evaluating educational courses (McLaren, 2010; Lowe \& Holton, 2005; Hong, 2002; Walker \& Hackman, 1992; Sherry, Fulford, \& Zhang, 1998). The appeal of the second period courses to the learners is reflected in the following quotations from the learners' answers to the open questions of the evaluation questionnaire:

"I wish that courses like this would be permanently running in the social and educational life in Leipsoi island", "I took advantage of my free time in creative and pleasant way and I came in contact with people miles away", "I heard that lifelong learning courses might stop and I strongly wish that this would not happen. It was the first time I attended these courses and, being unemployed it helped a lot to improve my skills, without cost, as well as my spirits and my self-esteem. I hope we meet again in September!", "Courses should keep on running, especially in remote island areas, as they provide a window of communication for the inhabitants and those who work there", "I got knowledge and skills which are very useful in both my personal and professional life".

All learners but one stated that they would certainly like to attend a similar course and all but three would suggest to someone else to attend.

As far as the strengths and weaknesses of the courses the answers of learners and educators have been categorized and are presented in Table 4. 
Table 4. Strengths and weaknesses of the courses according to the learners' and educators' views

\begin{tabular}{|c|c|c|}
\hline & Strengths & Weaknesses \\
\hline 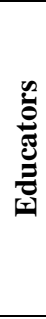 & $\begin{array}{ll} & \text { Educational opportunities without territorial } \\
& \text { restrictions } \\
- & \text { Education of people in remote areas } \\
\text { - } & \text { The technical support team of the program } \\
\text { - } & \text { Collaboration and interaction with the learners } \\
\text { - } & \text { Organization of the program } \\
- & \text { Interest shown by the learners } \\
- & \text { Educational material } \\
\text { - } & \text { Flexibility }\end{array}$ & $\begin{array}{ll}\text { - } & \text { Short duration of the course } \\
\text { - } & \text { Some learning groups were overcrowded } \\
& \text { Limited use of microphone and camera by the } \\
\text { - } & \text { Tearners } \\
\text { - } & \text { Different skill levels of learners in computer } \\
\text { - } & \text { Lack of educational material in some learning } \\
\text { courses }\end{array}$ \\
\hline & $\begin{array}{l}\text { - } \quad \text { Creative use of free time } \\
\text { - } \quad \text { Interesting learning subjects } \\
\text { - } \quad \text { Useful in professional development } \\
\text { - } \quad \text { Freedlexibility of the program } \\
\text { - } \quad \text { Collaboration and communication } \\
\text { - } \text { Acquirement of new knowledge and } \\
\text { updating the existing one } \\
\text { - The distance learning } \\
\text { Familiarization with the internet and the } \\
\text { - } \quad \text { The educator } \\
\text { - Pleasant course and interesting activities } \\
\text { - } \quad \text { Imssibility to learn in remote areas } \\
\text { Immediacy, convenient days and hours }\end{array}$ & $\begin{array}{l}\text { - Technical problems (i.e. low Internet speed in } \\
\text { the islands, insufficient technical equipment, } \\
\text { poor audio signal sometimes, the platform } \\
\text { could not support more than } 4 \text { web cameras } \\
\text { simultaneously) } \\
\text { - Short duration of the course } \\
\text { - Certain courses (theater workshop, and, } \\
\text { photography workshop) seem incompatible } \\
\text { with e-learning } \\
\text { Lack of immediacy with the other learners due } \\
\text { to limited use of microphones } \\
\text { Large number of learners in some courses, } \\
\text { classes should be limited to } 10 \text { persons }\end{array}$ \\
\hline
\end{tabular}

The evaluation results on the educators, whose the important role in online learning is stressed in literature (An, Shin, \& Lim, 2009; Salmon, 2004; Rovai, 2007), are very encouraging. As shown in Table 5 the vast majority of learners declared very satisfied by their educators at rates over $93 \%$ in all investigated parameters.

Table 5. Learners' appreciation of their educators in various parameters

\begin{tabular}{|c|c|c|c|c|c|c|}
\hline & \multicolumn{5}{|c|}{ Satisfied with the educator } & \multirow[b]{2}{*}{$\begin{array}{l}\text { Don't } \\
\text { know }\end{array}$} \\
\hline & $\begin{array}{l}\text { Not } \\
\text { at all }\end{array}$ & A little & So and So & Much & Very much & \\
\hline Preparation & $0.84 \%$ & $0.84 \%$ & $5.04 \%$ & $23.53 \%$ & $69.75 \%$ & \\
\hline Transfer of knowledge & $0.84 \%$ & $1.68 \%$ & $4.20 \%$ & $24.37 \%$ & $70.59 \%$ & \\
\hline Creation of collaborative spirit & $0.84 \%$ & $1.68 \%$ & $2.52 \%$ & $22.69 \%$ & $70.59 \%$ & \\
\hline $\begin{array}{l}\text { Responsiveness to learners during the } \\
\text { asynchronous learning periods }\end{array}$ & & $2.52 \%$ & $4.20 \%$ & $20.17 \%$ & $73.11 \%$ & $0.84 \%$ \\
\hline Committed & & & & $15.97 \%$ & $83.19 \%$ & \\
\hline $\begin{array}{l}\text { Facilitation of active learners' } \\
\text { participation during synchronous } \\
\text { meetings }\end{array}$ & $0.84 \%$ & $0.84 \%$ & $3.36 \%$ & $24.37 \%$ & $70.59 \%$ & \\
\hline $\begin{array}{l}\text { Facilitation of active learners' } \\
\text { participation during asynchronous } \\
\text { learning periods }\end{array}$ & $0.84 \%$ & $0.84 \%$ & $4.20 \%$ & $24.37 \%$ & $68.07 \%$ & $1.68 \%$ \\
\hline Best use of educational time & $0.84 \%$ & $0.84 \%$ & $4.20 \%$ & $21.85 \%$ & $72.27 \%$ & \\
\hline $\begin{array}{l}\text { Supplementary educational material, } \\
\text { notes, exercises provided by the } \\
\text { educator }\end{array}$ & & $0.84 \%$ & $3.36 \%$ & $27.73 \%$ & $68.07 \%$ & \\
\hline Response to the learner's needs & $0.84 \%$ & & $5.04 \%$ & $21.85 \%$ & $72.27 \%$ & \\
\hline
\end{tabular}

Expressing the views on the educational material, which was one of the weak points of the first period courses, the learners of the second period were very pleased at very high percentages as shown in Table 6 .

Analyzing the data of Table 6 the categories "much satisfied" and "very much satisfied" added together exceeded $80 \%$ in all the investigated aspects of the educational material. The learners found that the educational material was useful $(86.55 \%)$, understandable $(91.59 \%)$, it covered their needs $(81.51 \%)$, and interesting $(89.91 \%)$. They also rated the activities easy in content (88.23\%), easy to accomplish (89.07\%), and interesting (88.23\%). The possibility to store and reuse the material was also "much" and "very much" satisfactory $(94.95 \%)$, as was the quality of sound and image $(89.91 \%)$. 
Table 6. Learners' satisfaction in relation to the educational material

\begin{tabular}{|c|c|c|c|c|c|c|}
\hline & \multicolumn{5}{|c|}{ Satisfied with the educational material } & \multirow[b]{2}{*}{$\begin{array}{l}\text { Don't } \\
\text { know }\end{array}$} \\
\hline & Not at all & A little & So and So & Much & Very much & \\
\hline Useful & $0.84 \%$ & $3.36 \%$ & $7.56 \%$ & $34.45 \%$ & $52.10 \%$ & $1.68 \%$ \\
\hline Understandable & $0.84 \%$ & $0.84 \%$ & $5.88 \%$ & $29.41 \%$ & $62.18 \%$ & \\
\hline Covering the learners' needs & $1.68 \%$ & $2.52 \%$ & $14.29 \%$ & $27.73 \%$ & $53.78 \%$ & \\
\hline Interesting & $0.84 \%$ & $1.68 \%$ & $7.56 \%$ & $28.57 \%$ & $61.34 \%$ & \\
\hline Activities easy in content & & $0.84 \%$ & $10.92 \%$ & $37.82 \%$ & $50.42 \%$ & \\
\hline Activities easy to accomplish & & $0.84 \%$ & $9.24 \%$ & $33.61 \%$ & $55.46 \%$ & $0.84 \%$ \\
\hline Interesting Activities & $0.84 \%$ & $0.84 \%$ & $10.08 \%$ & $31.09 \%$ & $57.14 \%$ & \\
\hline Possibility to store and reuse & & $0.84 \%$ & $1.68 \%$ & $31.09 \%$ & $63.87 \%$ & $2.52 \%$ \\
\hline Quality of sound and image & $0.84 \%$ & $0.84 \%$ & $8.40 \%$ & $31.93 \%$ & $57.98 \%$ & \\
\hline
\end{tabular}

A very encouraging finding of this evaluation was that the weaknesses of the first period courses in the usability and the facilitation of communication, as well as the development of interaction between the participants through the Moodle platform appear to have improved considerably through the use of asynchronous and synchronous platforms in the second period.

The learners, in their vast majority, found the synchronous BBB platform:

- Usable ("very much" $57.98 \%$ and "much" $30.25 \%$ )

- Facilitating the communication with the educator ("very much" $58.82 \%$ and "much" $31.93 \%$ )

- Facilitating the communication between learners ("very much" 52.945 and "much" 33.61\%).

The learners highly appreciated the communication tools of the platform such as the synchronous discussion in the main forum and the possibility of a private conversation (the "very much" and "much" answers add to $86.55 \%$ ).

The asynchronous customized Moodle platform of the second period was considered to facilitate learners' communication with the educator at the same level as for the BBB platform ( $52.10 \%$ "very much" and $36.97 \%$ "much"), as well as the communication between learners (50.42\% "very much" and $33.61 \%$ "much"). The communication tools most used for the communication between educator and learners during the asynchronous sessions were:

- The forum ( $40.33 \%$ "very much" and $30.52 \%$ "much")

- The announcement board ( $40.33 \%$ "very much" and $24.36 \%$ "much")

- The chat ( $41.17 \%$ "very much" and $23.52 \%$ "much")

- The e-mail (30.25\% "very much" and $21 \%$ "much").

The communication tools most used for the communication between learners during the asynchronous sessions were:

- The chat (26.89\% "very much" and 19.32\% "much")

- The forum (15.12\% "very much" and $18.48 \%$ "much")

- The e-mail (13.44\% "very much" and 10.08\% "much").

The percentages of learners that did not use at all the e-mail (44.53\%), the forum (28.57) and the chat (19.32\%) for their communication with other learners are impressive but can be explained partly due to the fact that learners lived on the same island and knew each other, or the communication culture in an online environment was not sufficiently developed. Another interesting point is that the use of the forum and the chat as tools for the communication with the educator was higher than for the communication with other learners (70.85\% against $33.50 \%$ for the forum and $64.69 \%$ against $46.21 \%$ for the chat, respectively), something that can justified by the fact that learners live on a small island and can communicate live, while the educator is located far away.

Regarding the educators, despite the problems they met during the implementation of the courses (see Table 4), they all stated that they would like to continue teaching in e-LLLCs and in their vast majority (88\%) declared that they would like to be further trained in teaching online. Their preferences in training content were "teaching their subject online", 
"tools and good practices they could use online" and "lesson design by using web 2.0 tools". All the educators agreed that the training in the seminars implemented before the courses started was absolutely necessary and very important and useful, a view which is in line with the relevant literature (Elbaum, McIntyre, \& Smith, 2002; Salmon, 2004; Pavlis-Korres, 2010; Kearsley, 2000; Shank, 2004).

The main proposals by the learners were: "to resolve the technical problems", "to have blended courses for some thematic subjects", "to run smaller learning groups", "to increase the duration of the course in some thematic subjects" and develop extra levels for those intended to engage more and "to have the possibility of uploading the online meeting to the platform, so that absentees may catch up".

The main proposals by the educators were "to tackle the technical problems", "to have meetings between educators for the exchange of good practices", "the educators to be systematically and continuously trained", "learning groups to consist of 10 to 12 learners", "all learners to be familiarized with the use of the platforms" and "to have more courses and increase the duration in some thematic subjects".

\section{Conclusions}

The development of e-learning courses by the GSLLLY during the last decade is divided in two periods. The first period courses materialized from 2008 to 2011 and the second period courses from 2014 to 2016 . In the design of the second period courses the experience and the outcome of the evaluation of the first period courses were taken into consideration and effort was made to exploit the possibilities of educational technology and to integrate the principles of adult education in online courses. Basic elements in the design and implementation of the second period courses were the replacement of face to face meetings with synchronous online meetings, the training of the educators on teaching in an online environment, the better use of communication tools in both synchronous and asynchronous learning environment and the creation of interactive multimedia educational material.

As it comes out of the evaluation of the second period courses the handling of technical problems, the proper and continuous training of the educators on online teaching, the attractive multimedia educational material, the familiarization of the learners with the learning platforms and the use of synchronous communication tools resulted in the vast improvement of the first period weaknesses, which led to a positive response by the learners and enhanced the further development of online courses aiming to make these courses more attractive and efficient. The encouraging results of this evaluation further stress the importance of careful and detailed analysis of evaluation findings, as these form the prerequisites for the further improvement of online courses in the future overcoming space and time limits, offering educational solutions to remote areas, as in our case to the scarcely inhabited Greek islands.

\section{Acknowledgements}

I would like to thank the GSLLLY and INEDIVIM teams for their help in providing data concerning the first period and the second period courses.

\section{References}

An, H., Shin, S., \& Lim, K. (2009). The effects of different instructor facilitation approaches on students' interactions during asynchronous online discussions. Computers \& Education, 53(3), 749-760. https://doi.org/10.1016/j.compedu.2009.04.015

Bonk, C. J. (2009). The world is open: How web technology is revolutionizing education. San Francisco, CA: Jossey-Bass.

Bonk, C. J., \& Cunningham, D. J. (1998). Searching for learner-centered, constructivist, \& sociocultural components of collab educ lrng tools. In C. J. Bonk, \& K. S. King (Eds.), Elec. collaborators: Learner-centered teachers' for literacy, apprenticeship, \& discourse (pp. 25-50). Mahwah, NJ: Erlbaum.

Bonk, C. J., Wisher, R. A., \& Nigrelli, M. L. (2005). Learning communities, communities of practice: Principles, technologies, and examples. In K. Littleton, D. Miell, \& D. Faulkner (Eds.), Learning to collaborate, collaborating to learn (pp. 199-219). New York: Nova Science Publishers, Inc.

Edelson, D. C. (2001). Learning-for-use: A framework for integrating content and process learning in the design of inquiry activities. Journal of Research in Science Teaching, 38(3), 355-385.

https://doi.org/10.1002/1098-2736(200103)38:3<355::AID-TEA1010>3.0.CO;2-M

e-kdvm. (2015). Website of the Program "Municipal Centers for Lifelong Learning in Central Greece and South Aegean", www.e-kdvm.gr

Elbaum, B., McIntyre, C., \& Smith, A. (2002). Essential elements: Prepare, design, and teach your online course. Atwood Publishing. 
Gortan, A., \& Jereb, E. (2007). The Dropout Rate from E-Learning Courses and the Satisfaction of Students with E-Learning. Organization, 40(6), 248-257.

GSLLLY (2012). Specifications for the implementation of the courses by Municipal Centers for Lifelong Learning in Central Greece and South Aegean. Document number 9250/26-9-2012.

Henderson, M., Selwyn, N., \& Aston, R. (2015). What works and why? Student perceptions of useful digital technology in university teaching and learning. Studies in Higher Education, 1-13. http://dx.doi.org/10.1080/03075079.2015.1007946

Hillman, D., Willis, D., \& Gunawardena, C. (1994). Learner-Interface Interaction in Distance Education: An Extension of Contemporary Models and Strategies for Practitioners. The American Journal of Distance Education, 8(2), 30-42. https://doi.org/10.1080/08923649409526853

Hong, K. S. (2002). Relationships between students' and instructional variables with satisfaction and learning from a Web-based course. The Internet and Higher Education, 5(3), 267-281. https://doi.org/10.1016/S1096-7516(02)00105-7

IDEKE, (2011a). Data from the courses' archives.

IDEKE, (2011b). Data from the courses' archives.

Kearsley, G. (2000). Online education: Learning and teaching in cyberspace. Belmont, CA: Wadsworth/Thomson Learning.

Lally, V., \& Barrett, E. (1999). Building a learning community on-line: towards socio-academic interaction. Research Papers in Education, 14(2), 147-163. https://doi.org/10.1080/0267152990140205

Law 3879/2010. Development of Lifelong Learning and other provision. Official Government Gazette of the Hellenic Republic. Volume one. Issue no: 163, 21st September 2010.

Leftheriotou, P., \& Pavlis, K. M. (2014). General Adult Education Programs by the General Secretariat of Lifelong Learning: past, present, and future. In A. Kyridis, Vulnerable Social Groups and Lifelong learning (pp. 151-193). Athens: Gutenberg. (in Greek)

Levy, Y. (2007). Comparing dropouts and persistence in e-learning courses. Computers \& Education, 48 (2), 185-204. https://doi.org/10.1016/j.compedu.2004.12.004

Lowe, J. S., \& Holton, E. F. (2005). A theory of effective computer-based instruction for adults. Human Resource Development Review, 4(2), 159-188. https://doi.org/10.1177/1534484305276301

McLaren, A. C. (2010). The effects of instructor-learner interactions on learner satisfaction in online masters courses. Ph.D. dissertation, Wayne State University, Detroit, MI.

Merlose, S., \& Bergeron, K. (2007). Instructor immediacy strategies to facilitate group work in online graduate study. Australasian Journal of Educational Technology, 23(1), 132-148.

Moore, M. G., \& Kearsley, G. (1996). Distance Education: A systems view. Belmont. CA: Wadsworth.

Moore, M., G. (1989). Three types of interaction. The American Journal of Distance Education, 3(2), 1-6. https://doi.org/10.1080/08923648909526659

Neoanalysis. (2011). Final External Evaluation Report of the Program "Design and Implementation of Distance Learning Programs via Lifelong Learning Center". Athens, Greece. (in Greek).

Osborn, V. (2001). Identifying at-risk students in videoconferencing and web-based distance education. The American Journal of Distance Education, 15(1), 41-54. https://doi.org/10.1080/08923640109527073

Palloff, R. M., \& Pratt, K. (2003). Virtual student: A profile and guide to working with online learners. San Francisco, CA: Jossey-Bass.

Panneer Selvam, S. K. (2009). Distance education in the 21st century. New Delhi: A.P.H. Publishing Corporation.

Park, J. H., \& Choi, H. J. (2009). Factors Influencing Adult Learners' Decision to Drop Out or Persist in Online Learning. Educational Technology \& Society, 12(4), 207-217.

Parker, A. (1999). A study of variables that predict dropout from distance education. International Journal of Educational Technology, 1(2), 1-12.

Pavlis-Korres, M. (2010). Development of a framework for the e- education of educators of special groups aiming to improve their compatibility with their learners. Ph.D Thesis. Spain:University of Alcalá. 
Pavlis-Korres, M. (2011). Final Internal Evaluation Report of the Program "Design and Implementation of Distance Learning Programs via Lifelong Learning Center”. Athens, Greece. (in Greek).

Pavlis-Korres, M. (2012). The Role of the Communication Tools in the Development of the Learning Group in an Online Environment. International Journal of Engineering Education, 28(6), 1360-1365.

Pavlis-Korres, M. (2013). Key Factors for Maximizing the Effectiveness of Blended E-Learning: The Outcome of the Internal Evaluation of a Distance Education Program for Adult Learning in Greece. In L. Kyei-Blankson \& E. Ntuli (Eds.), Practical Applications in Blended Learning Environments: Experiences in K-20 Education (pp. 410 437). USA: IGI Global. https://doi.org/10.4018/978-1-4666-9582-5.ch008

Pavlis-Korres, M., \& Leftheriotou, P. (2016). Building Interaction in Adults' Online Courses: A Case Study on Training E-Educators of Adutls. In Kyei-Blankson, L., Ntuli, E. \& Agyeman, C., Handbook of Research on Strategic Management of Interaction, Presence and Participation in Online Courses (pp. 185-215). USA: IGI-Global.

Pavlis-Korres, M., \& Nikolopoulou, V. (2015). Designing e-LLC, responding to contemporary requests. In Conference Proceedings,"Lifelong Learning and Modern Society: Local Government, Education, Labour", University of Macedonia. (in Greek, in publish).

Rostaminezhad, M. A., Mozayani, N., Norozi, D., \& Iziy, M. (2013). Factors Related to E-learner Dropout: Case Study of IUST Elearning Center. Procedia-Social Behavioral Sciences, 83, 522-527. https://doi.org/10.1016/j.sbspro.2013.06.100

Rovai, A. P. (2003). In search of higher persistence rates in distance education online programs. Internet and Higher Education, 6, 1-16. https://doi.org/10.1016/S1096-7516(02)00158-6

Rovai, A. P. (2007). Facilitating online discussions effectively. The Internet and Higher Education, 10(1), 77-88. https://doi.org/10.1016/j.iheduc.2006.10.001

Salmon, G. (2004). E-Moderating: The Key to Teaching and Learning Online. London: Taylor and Francis, 2nd ed.

Savenye, W. C., Olina, Z., \& Niemczyk, M. (2001). So you are going to be an online writing instructor: Issues in designing, developing, and delivering an online course. Computers and Composition, 18(4), 371-385. https://doi.org/10.1016/S8755-4615(01)00069-X

Sawang, S., Newton, C. J., \& Jamieson, K. (2013) Increasing learners' satisfaction/intention to adopt more e-learning. Education + Training, 55(1), 83-105. https://doi.org/10.1108/00400911311295031

Shank, P. (2004). Competencies for online instructors. In Learning Peaks, LLC. Retrieved on 22 February 2009, from http://www.insighted.com/instrcomp.pdf

Sherry, A. C., Fulford, C. P., \& Zhang, S. (1998). Assessing distance learners' satisfaction with instruction: A quantitative and a qualitative measure. American Journal of Distance Education, 12(3), 4-28. https://doi.org/10.1080/08923649809527002

Walker, K., \& Hackman, M. (1992). Multiple predictors of perceived learning and satisfaction: The importance of information transfer and non-verbal immediacy in the televised course. Distance Education, 13(1), 81-92. https://doi.org/10.1080/0158791920130107

\section{Copyrights}

Copyright for this article is retained by the author(s), with first publication rights granted to the journal.

This is an open-access article distributed under the terms and conditions of the Creative Commons Attribution license which permits unrestricted use, distribution, and reproduction in any medium, provided the original work is properly cited. 